\title{
Neoliberal discourses in Spanish for business: An ethnographic classroom study
}

\author{
Jesse W. Rubio
}

Abstract: Beginning in the 1970s, education has responded to the rise of neoliberalism across macro-, meso-, and micro-level contexts through shifts in practice and structure. Meanwhile, language learning is often promoted as an instrument in job attainment and transnational business communication. For example, in language education, courses in language for specific purposes, whose ubiquity continues to increase, often reflect the market rationality embedded in contemporary education and support an instrumental orientation to language learning. This ethnographic study investigates the neoliberal discourses taken up by students and the instructor in a university-level Spanish for Business classroom. Drawing on triangulated data from classroom observations, field notes, informal interviews with students and the instructor, and a semi-formal interview with a focal student participant, the findings suggest that competition, compliance, and individualism were among the ideological discourses of the classroom. However, while societal and institutional discourses of neoliberalism were often interpellated, they were also resisted. Implications for praxis are also discussed.

Keywords: Spanish for business, neoliberalism, competition, compliance, individualism

Over the past century, language educators have adopted various pedagogical methodologies and strategies in efforts to promote language acquisition. Spanning from the grammar-translation methods of 1800 s and early 1900s through to the current trends in communicative language teaching (González, 2008), language instruction methods build on and reflect both second language acquisition theories as well as broader, macro-level social 
and political goals. Since the early 1990s (Fryer, 2012), language for specific purposes (LSP) classes have become ubiquitous in the United States in institutions of language education, including private commercial language schools, public adult education programs, and universities. Such courses address language use and the specific linguistic forms characteristic of specialized fields, such as science and technology (e.g., Swales, 1988), medicine (e.g., Plastina, 2016), and law (e.g., Curran, 1993). However, within the United States, the language of business has remained the most prevalent subject of LSP courses in universities for the past 30 years (Long \& Uscinski, 2012).

Likewise, the intensified globalization of capitalism has had major ideological implications for both language use and education over the past few decades (Au, 2018; Giroux, 2011; Piller \& Cho, 2013). Languages and knowledge of language have economic value that may be leveraged in the global marketplace; multilingual competence contributes symbolic and material value to the resumes of individuals seeking employment in transnational businesses and, therefore, has essentially been commoditized on a previously unprecedented scale (De Costa, Park \& Wee, 2016; Urciuoli, 2016). Of course, the commodification of language has influenced the goals, structure, and content of language education. Students are often encouraged to enroll in language courses because it has been deemed necessary for conducting transnational business successfully (Lindholm-Leary, 2000). Meanwhile, languages that are frequently used to conduct transnational business-Chinese, Korean, Japanese, Arabic, and Spanish-have seen a rise in popularity in universities, according to the Modern Language Association (Looney \& Lusin, 2018). Language departments throughout the United States consistently offer courses in these languages due in part to their instrumentality as “a key element of [corporate] firms' international operations" (Piekkari, Welch \& Welch, 2014, p. 230). Universities have specifically targeted the neoliberal goals of language learning by developing and implementing language for business courses. While prior research has investigated practices in LSP more generally with regard to curriculum design and implementation (Serafini \& Torres, 2015; Spring, 2012) and in English language education contexts (Chun 2009; Hadley, 2015), these studies have demonstrated a need for additional analysis. Particularly, closer examination of how macro-level neoliberal discourses are manifest in the micro-level business language classroom and how students contribute to and take up such discourses may elucidate mechanisms for perpetuating-or misinterpellation of (Martel, 2017)_capitalist ideologies in language learning as both an outcome and a process. It may further contribute to the generation of 
theories about student identity performativity within an LSP context. Indeed, since "developing knowledge on specific situations and communities is a necessary starting point for model-building" (Canagarajah, 2006, p. 154), this investigation may have implications for pedagogical practice and organizational decision-making in language programs, colleges, and universities.

This study uses ethnographic methodology to examine "the local form of general properties of social life-patterns of role and status, rights and duties, differential command of resources, transmitted values and environmental constraints" (Hymes, 1996, p. 14). Using recursive content analyses (Heath \& Street, 2008) and abductive logic (Agar, 1996), I aim to gain a greater understanding of the local linguistic and cultural practices in a Spanish for Business undergraduate level course and the impact of those practices on student positionalities.

\section{Neoliberal Ideology and Language Education}

Among the dominant ideologies that shape social life in the United States, notably in business, is that of neoliberalism. The term, though contested in the literature (Gray, O'Regan, \& Wallace, 2018; Rowe, Lubienski, Skourdoumbis, Gerrard \& Hursh, 2019), is used in this study to refer broadly to an ideology and "theory of political economic practices that proposes that human well-being can best be advanced by liberating individual entrepreneurial freedoms and skills within an institutional framework characterized by strong private property rights, free markets, and free trade" and that emphasizes "[d]eregulation, privatization, and withdrawal of the state from many areas of social provision" (Harvey, 2005, p. 2-3). Though limited space prevents a thorough historical account, briefly, neoliberalism was borne out of the oil crisis and economic recessions across several countries in the 1970s, including the United States, and served as both a radical economic response to these crises and as a system that aligned with policy makers' own views that valued individualism and profit through competition (Chun, 2016; Gray, O’Regan \& Wallace, 2018; Olssen \& Peters, 2005) while rewarding obedience to existing structures (Martin-Sanchez \& Flores-Rodriguez, 2018). Since then, neoliberal ideology has grown increasingly dominant and hegemonic in social institutions, including that of education.

In higher education, neoliberal ideology has influenced shifts and practice in language instruction. More specifically, business language courses represent unique sites of neoliberal reproduction. Though business language 
courses have been offered in the United States since after World War II, they saw a rise in popularity near the end of the $20^{\text {th }}$ century due in part to the transnational expansion of corporations that took place with increased Internet access and the opening of China and India to the global economy (Fryer, 2012). Universities recognized the demand for multilingualism, yet the purposes of language learning have remained a topic of debate. Whereas some institutions perceive language in terms of its humanistic elements and its affective benefits, many view language as an instrument to "support the needs of the students they serve" (MLA, 2007), which relate largely to employability (Fryer, 2012; Holborow, 2007; Long \& Uscinski, 2012). These discourses of instrumentality suggest the use of language as a tool for meeting individualistic and competitive needs that are seen as relevant in students' lives and are reflected in the growing number of business language courses offered in universities. In Long and Uscinski's (2012) survey study of LSP courses in the United States, business language courses were offered in $70 \%$ of the language departments surveyed, and $76 \%$ wanted to include or add more business language courses in the future. Further, the federal government has reinforced the instrumental perspective on language and the growth of business language curricula through its allocation of funds. For instance, the U.S. Department of Education has funded 15 public and private universities with over $\$ 4.5$ million to be used to advance transnational business and trade (U.S. Department of Education, 2018). These trends exemplify the global ascendency of neoliberal ideology and specifically denote its penetration in education.

Furthermore, the ubiquity of languages for business courses both constitutes neoliberal ideology and normalizes and perpetuates it. Among the stated goals of language for business courses is developing an understanding of "language matters, or issues, that play an important role in furthering, or impeding, global expansion" (Piekkari, Welch \& Welch, 2014, p. 2). Enrollment in these courses, then, serves instrumental goals of language learning that are neoliberal in nature. However, this is not unique to business-focused curricula. In his study of an English for Academic Purposes course, Chun (2015) found that neoliberal discourses of globalization, which were embedded in the course materials, were readily taken up by the instructor and students, demonstrating the ideology's hegemonic presence and prevalence. At the institutional level, Holborow (2007) discusses how the use of neoliberal ideological metaphors throughout universities, such as the reference to students as "customers" (p. 61), illustrates the depth of saturation of neoliberal ideology in education. Neoliberalism, which is conceptually built on the promotion of the free market, also relies on com- 
petition and individualism (Giroux, 2011; Olssen \& Peters, 2005). These concepts are evident in universities, for example, through their admissions and ranking practices (Aronowtiz, 2008; Piller \& Cho, 2013). Moreover, before students enroll in institutions of higher education, universities recruit potential students by appealing to a "lifestyle" and to the market "value" of education in promotional materials (Chun, 2009, p. 115). Given the functional and symbolic role of neoliberal ideologies in education, language for business courses serve as micro-level sites for the potential continued normalization of such ideologies and for the preparation of capitalist workers in transnational businesses. However, potential resistance to neoliberal ideology also exists in these classrooms through critical pedagogy and reflection (Au, 2018; Giroux, 2011). In this study, I examine these tensions as they are negotiated in one Spanish for Business classroom.

\section{Identity and Investment in Language Learning}

While ideology plays an important role in language education, it does not solely determine how students approach language learning. Identity, which is not entirely separable from ideology, has been investigated in multiple contexts and from various perspectives as another factor influencing language attitudes and learning experiences (Bergman, Watrous-Rodriguez \& Chalkley, 2008; Cummins, Hu, Markus \& Kristiina Montero, 2015; Faircloth, 2012; Morgan, 2004; Norton Peirce, 1995; Talmy, 2010). Though studies on identity previously approached the construct as a set of relatively static categorizations, more current research suggests that it is developed socially and continuously, situated contextually, and at times contradictory (Block, 2007; Hall, 1996; Kramsch, 2009; Norton, 2000; Norton \& Toohey, 2011). Moreover, this approach to identity—known as poststructuralismconsiders the multiplicity of potential positionalities that may be invoked in interaction. In other words, the variable positions learners assume in language classrooms are discursively constructed using multimodal semiotic systems, which are further complicated since multilingual language users position themselves "depending on which language they choose to use, with whom, on which topic, and depending on the different memories evoked by different codes as well as the different expectations each of these codes raises in their interlocutors" (Kramsch, 2009, p. 20). In the context of a language classroom, therefore, a poststructuralist notion of identity and the symbolic systems that emerge in situated discourse are central in analyzing students' linguistic and social practices and in acknowledging student agency. 
Along with identity and ideology, Darvin and Norton (2015) proposed a framework of investment in language learning that incorporates Bourdieu's (1991) notion of capital, as well. This framework suggests the crucial influence of these complex, overlapping concepts on language students and highlights the relationship between language and power. Though identity and investment will not be discussed at length here, they are important theoretical constructs in language classroom and learner identity research.

\section{Discourse and Power}

As in language learning investment and identity development, power impacts the conceptualization and adoption of educational discourses. Foucault (1981) identifies discourse as "one of the places where...politics exercise[s] in a privileged way some of [its] most formidable powers" (p. 52). In other words, dynamics of power and status, ideologies, and historical contexts shape and legitimate the discourses, or ways of understanding, that circulate and become dominant in society. However, power, while not monolithic, is also differentially available among individuals and thus materially influences which-and importantly whose-discourses are valued within society (see Cameron, Frazer, Harvey, Rampton \& Richardson, 1992). Discourses, therefore, operate across the macro- and micro-levels of society. Moreover, since learning and its discourses are never neutral (Giroux, 2011), control may be exerted over students to some degree according to their own and others' political power as they participate in institutions of education. In a Spanish for Business classroom, for example, the discourses that are made readily available to students are determined in part by sociopolitical restrictions (Foucault, 1981). These restrictions, situated within the discourses that shape the fields of language and business as well as within higher education and society more broadly, may include individuals' relative social, cultural, and symbolic capital (Bourdieu, 1991), their identity positionality (Norton \& Toohey, 2011), and notably, hegemonic ideologies, such as those of neoliberalism discussed above. Due to the inequity and differentiation these structures often create and perpetuate (Aronowitz, 2008; Eckert, 1989; Giroux, 2011; Willis, 1977), and in order to uncover their local semiotic manifestations, a critical approach to classroom discourse must be adopted that may determine "the ways that social relationships are lived out in language and how issues of power, while often obscured in language research and educational practice,... are centrally important" (Norton \& Toohey, 2004, p. 1).

Similarly, as suggested above, discourse may not be separated from con- 
text. Goffman's (1964) notion of the social situation, defined "as an environment of mutual monitoring possibilities, anywhere within which an individual will find himself accessible to the naked senses of all others who are 'present,' and similarly find them accessible" (p. 135), suggests that discourse comprises not only the indicative and correlational features of interaction, but the situational, as well. That is, a robust analysis of context considers the qualities, structures, and extralinguistic aspects of texts, the relevant social backgrounds of interlocutors, and the symbolic and physical relationships both among interlocutors and within the micro-, meso-, and macro-level social environments. The contexts involved in the Spanish for Business class, therefore, range from students' utterances in classroom talk (Gumperz, 1992) to the societal ideological discourses that influence the structure of the university and the distribution of power therein. Schegloff (1992), though, argues that relevance is central in contextual analysis. The relevant features of context are determined by interlocutors rather than imposed by the researcher and are invoked in talk and, more generally, the given social situation, including institutional frames (Cicourel, 1992). As such, this study attends to the multiple levels of context made relevant by participants through multimodal discourse.

\section{Methodology}

\section{Spanish for business at a business-oriented university}

The Spanish for Business class that serves as the site for this ethnographic study was held on a university campus in the Northeast region of the United States. The university's core undergraduate curriculum focuses heavily on business, with over half of the major areas of study offered representing some segment within the corporate structure. It is well known for its students' high rate of employment and starting salary after graduation, and it advertises to potential students with statistics touting such claims and with national rankings determined by popular media outlets. These promotional discourses are associated largely with the business curriculum and extracurricular activities offered by the university, such as internships with transnational corporations. Therefore, the humanities, including the language department, have relatively low status within the institution both symbolically and materially. With the majority of registered students interested primarily in business studies, the few degrees that are offered in the humanities are sparsely advertised, and the departments therein are relegated to the older buildings on campus with fewer resources. The public messages regarding educational goals and post-graduation priorities, the 
hierarchy of academic subject areas, and the spatial arrangement of the campus jointly convey the ideological discourses endorsed by the university (Foucault, 1981; van Leeuwen, 2008).

Consistent with these structures, few language courses are offered at the university, and less than $5 \%$ of the student population studies language beyond the intermediate level. However, the Spanish for Business course consistently attracts greater numbers of students compared with other courses in the department. The class that was observed for this study had 22 students, of whom 21 were pursuing degrees in business. Data were collected over two months through classroom observations and included field notes along with informal interviews with students and the instructor and one semi-formal interview with a student-Katarina, who identified as a cisgender female-which was audio-recorded and transcribed. Throughout data collection, I adopted a constant comparative approach in order to "keep looking in multiple ways and directions" (Heath \& Street, 2008, p. 32). Based on the review of the literature, initial analyses of field notes, and informal discussions with participants (Agar, 1996), I noted several topics to guide the informal interview after my second observation and selected participants for case study. Katarina was chosen as a focal student for this study due to the identity positions she adopted during classes and in our unstructured interactions. Having selected economics as her major field of study and Spanish for Business as her minor, as well as having recently completed a study abroad program in Perú, she demonstrated both the commitment to business embodied by the university and a dedication to learning Spanish. Her linguistic engagement in the course was also representative of the general patterns of participation that emerged among most students. The interview conducted with Katarina thus aimed to elicit information about her investment in language learning, Spanish, and Spanish for business; her perceptions of language learning and use; and her identity as a Spanish user and business student (Darvin \& Norton, 2015; Kramsch, 2009; Schegloff, 1992).

My positionality as a participant observer in this study was potentially complicated by my prior teaching experience and my familiarity with the site and with several faculty members throughout the university. In order to make the familiar setting strange and enhance the study's validity, in addition to adopting a constant comparative perspective, I reflected recursively on and disclosed my identities to participants (Heath \& Street, 2008). Further, I relied on theory and triangulation of data throughout analyses to consider the data from multiple viewpoints and in different ways (Agar, 1996). 


\section{Data analysis}

Analysis was iterative, using rich points in the discourse to develop thematic cultural and linguistic frames, which were constantly reconsidered and adjusted (Agar, 1996). This process involved transcription of the audiorecorded interview data, multiple readings of field notes and transcriptions, revisiting the literature, and coding and categorization of patterns and divergences from patterns across the data. After several rounds of interpretive analysis, three major recurring themes were identified-peer competition, compliance with authority, and individualism. Though analysis was conducted drawing on Foucault's (1981) notion of discourse, a multidimensional understanding of context (Goffman, 1964; Goodwin \& Duranti, 1992), and a poststructuralist perspective, this study was abductive, allowing for "the development of new theoretical propositions" (Agar, 1996, p. 35). Therefore, the goal of analysis was to reveal the contextual and social factors influencing cultural and linguistic practices and student identity performativity in a Spanish for Business classroom.

\section{Findings}

In a classroom, as in any social context, multiple layers of context and various discourses may be at play. The following sections discuss how the Spanish for Business students in this study constructed their learning experiences and their identities discursively, suggesting the interpellation of neoliberal ideologies and at times, defying them.

\section{Competition}

Education is an important institution for perpetuating dominant ideologies such as neoliberalism, which "emphasizes winning at all costs, even if it means a ruthless competitiveness" (Giroux, 2011, p. 9). A central component of neoliberal ideology that was taken up by the Spanish for Business students was such an emphasis on competition. During one lesson, the instructor of the class designed an activity that functioned as a competitive stage for students. The activity was structured as a game in which students earned points by correctly guessing hidden lexical items based on the descriptions provided in Spanish by their team of three or four students. Throughout this activity, all students' semiotic messages signaled ardent desire for victory. Their engagement was manifested physically, as they hovered excitedly over their chairs and whispered to strategize how to best describe the hidden words. When students guessed correctly, they 
often smiled, nodded, high-fived a teammate, explained how they remembered the word/phrase, or sighed in relief. They requested frequent updates from the instructor on which team had gotten the most correct responses. Indeed, it was almost exclusively during competitive activities such as this that the Spanish for Business students' investment in language learning was concretely embodied through linguistic and paralinguistic cues. Collaborative activities, on the other hand-including small-group and whole-class discussions, student presentations and lectures, and individual work-were done in a calm, relaxed manner, with students leaning on their desks, resting their heads in their hands, or slouching in their chairs, and were often characterized by long stretches of silence.

While this contrast marked competitive activities on several occasions and across all students in the classroom, the neoliberal emphasis on "winning at all costs" was intensified during the last turn of this game. The instructor had announced each group's scores, and the final group was tied for first place with the other teams. They needed only one more correct answer to secure their victory. According to the rules of the game, an answer in Spanish earned two points and an answer in English earned one. The team immediately opted to respond in English for the final turn because "that's all we need to win." The class's linguistic and semiotic expression of excitement and investment throughout the activity suggested their ready enthusiasm for the competition. However, this discourse was elevated in the leading team's stated goal of winning, rather than of producing the lexical item in Spanish as an activity in language learning.

Further, students actively created competitive situations in the classroom. For example, during a translation activity, students were asked to replace words in sentences with other pragmatically appropriate items. When the instructor asked the class to share their answers, two students initiated a competition to answer first. After the instructor presented each prompt, these students called out several times without pause and with increasing speed, their speech overlapping as they raced to be the leading voice in the class. In participating in this competition, the students attempted to demonstrate competence and to position themselves as the superior Spanish user in the class. They thereby contributed to an ideological differentiation of "those who are allowed to progress...from those who are forced to bear the burden of underperformance by being relegated to a progressively shrinking sphere of opportunity" (Piller \& Cho, 2013). Though the stakes were relatively low in these classroom competitionswhether designed by the instructor or developed by the students-such 
competitive practices illustrate the reach of neoliberal ideology in the language classroom.

Students' interpellation of discourses of competition extended beyond the immediate classroom setting, as well. During a small group discussion on the affordances and drawbacks of collective societies, one group stated that "un problema con el colectivismo es que se puede tener una vida normal sin hacer un trabajo...no existe la motivación personal porque todos tiene lo mismo" (A problem with collectivism is that you can have a normal life without working...there is no personal motivation because everyone has the same things). Students in other groups, including Katarina, agreed that collective societies are problematic because "no hay motivación" (there is no motivation). The lack of competition in society, according to the students, is linked to a lack of motivation. Conversely, competition is framed as a motivating force that produces lives that may be "normal," or they may be better or worse than those of others. This orientation to society illustrates the Spanish for Business students' assessment of competition as a necessary component of social life.

Moreover, motives to learn languages may also be linked to competition in the neoliberal corporate structure. De Costa, Park, and Wee (2016) argue that when it is "an act of aligning with the moral imperative to strategically exploit language-related resources for enhancing one's worth in the world" (p. 696), a student's motivation for learning a language is an embodiment of linguistic entrepreneurship. In Katarina's interview, when asked why she chose to take language courses at the university level, she discussed her hope to use Spanish in her future career as a macroeconomist.

Katarina: I'm minoring in Spanish for Business...I really love taking the Spanish classes. I think this one [Spanish for Business] is super helpful because it's very focused towards actually like what kind of Spanish are you gonna need when you're actually working in a business.

Among the various cultural and linguistically focused courses offered at the university, Katarina particularly named the Spanish for Business course as "super helpful." She attributes this positive evaluation to its curriculum, which addresses the language that she "actually...[is] gonna need" when she is "actually working," as opposed to the language she uses in other domains where, in contrast, she may not "actually" need or use her knowledge of Spanish. She also explained that she opted to minor in Spanish for Business, 
rather than pursuing the more generalized minor offered in Spanish at the university, to support her aspirations to work in a corporation abroad and to "get in contact with Spanish-speaking countries." She further achieved this through participation in a study abroad program in Spain where she took a course in the Development of Business in the $21^{\text {st }}$ Century. The language learning opportunities in which she chose to engage thus appeared to only offer skills and knowledge that would apply directly to her career. Through her discursive construction of motivation, Katarina connected her investment in learning Spanish exclusively to her success in business, suggesting that her language learning was driven largely by her desire to gain greater economic, social, and cultural capital that would prove beneficial in competitive neoliberal society (Darvin \& Norton, 2015; Kramsch, 2009).

\section{Compliance}

While competition was a central practice of the Spanish for Business classroom, compliance was, as well. The neoliberal structure in education requires individuals' compliance with and consent to the demands of a hierarchy that obedience both creates and maintains. This is done in part through the establishment of rules for social behavior and through measurement of accountability, which are imposed externally and reinforced internally (Harland, Tidswell Everett, Hale \& Pickering, 2010; Martin-Sanchez \& Flores-Rodriguez, 2018; Olssen \& Peters, 2005). Within the Spanish for Business classroom, the instructor's dominance in the hierarchy was secured in the students' discursive practices. Students consistently complied with the instructor's orders unquestioningly and without complaint. When he told them to put away their laptops, they immediately did so; when he assigned students to groups for discussion, they transitioned silently to the assigned area of the room; when they attempted to use English in small groups and he demanded they speak "en español," they did so and continued using Spanish when he walked away; when he moved to the front of the room, the students fell quiet. As the dominant member of the classroom community, the instructor dictated the classroom's physical and verbal content. However, a hierarchy emerged among the students, as well. The same three students represented the majority of voluntary whole-class talk. Though other students would speak during such discussions, they only did so when the instructor called on them. These three students also gave extended responses, such as "Es importante para poder comunicarse con los clientes" (It is important to be able to communicate with clients), whereas other students in the class tended to provide one- and two-word answers. In smaller groups, all students spoke within a five-minute timespan, yet in the shift to 
whole-class talk, the same three students served as self-appointed proxies for the groups. Though these dominant students might have assumed these roles for many different reasons, identity is discursively constructed with regard to relations of power, and by claiming the right to speak (Norton Peirce, 1995), these students positioned themselves as more powerful while many other students consented to remain relatively silent and powerless.

Moreover, the Spanish for Business students' consent to a hierarchical structure was also expressed explicitly and applied to business contexts. During a small-group discussion, the instructor posted a question for the group to answer: ¿Cuál es un elemento importante en una oficina? (What is one important element in an office?). After several minutes of discussion, each group shared an answer with the whole class. One group said that an office needed "un jefe" (a boss). Students from other groups nodded in agreement, "Si, necesitamos un jefe en una oficina" (Yes, we need a boss in an office). They acknowledge and accept the structure that maintains obedience in business, wherein a more powerful individual sets rules and ensures accountability of the less powerful employees. This is mirrored in the university's extensive efforts to ensure students have secured jobs before graduating in order to maintain their post-graduation employment rate.

Katarina: [The university] has a huge push, like, we're going to get you a job and an internship. This is what's going to happen. So they're really helpful with making sure you have the experiences, like here's how you make a LinkedIn profile, here's how you write a resume, here's how you write a cover letter. The Careers Services department is awesome...it's like teaching you how to be in front of these people [potential employers] so you will have a job before you graduate...There's a lot of pressure to get hired before you graduate, which is good, but I realize it's very different from other universities.

The university exerts its power to control students' decisions and to hold them accountable to an institutional, capitalist definition of success. This discourse is often taken up by students, as evidenced by the university's consistently high post-graduation employment rate. The corporate structure and behavioral expectations therein are made "normal" as students move through the public education system over many years (Apple, 2004; Eckert, 1989). When they enter post-secondary education, compliance either remains an assumed classroom practice and hegemonic institutional expectation that seamlessly carries into corporate life, or it may be unlearned and resisted (Au, 2018; Aronowitz, 2008). 


\section{Individualism}

While the discourses of competition and compliance were readily interpellated by students in the Spanish for Business class, individualism was taken up more variably. The notion of individualism in neoliberal society approaches "individuals as economically self-interested subjects" who make decisions according to their "own interests and needs" (Olssen \& Peters, 2005, p. 314). These discourses of individualism were apparent during the competitive vocabulary game described in a previous section. Each of the student teams in the class could earn points during the game when a hidden lexical item was guessed correctly. The leading team had two options in their last turn: These four students could give the correct response, win the game, and have two points added to their last exam scores, or they could opt to not answer the final question, resulting in a tie for first place among all of the students in the class and in two points being added to all students' exams. When the instructor asked the team what they wanted to do, they decided that "tomamos los puntos" (we'll take the points) and gave the response in English. Given the opportunity to offer everyone in the class a higher grade, these students attended exclusively to their own interests.

Students in the class also seemed to approach language learning as an individual enterprise. On several occasions, the instructor assigned group work in which three or four students sat clustered together with the aim of accomplishing an assigned task, yet with few exceptions, the class chose to work alone instead. Individuals sat huddled reading and writing over their books and computers, speaking in either Spanish or English only when prompted by the instructor to do so. When discussing her favorite classroom activities in the Spanish class, Katarina also expressed a preference for individual work.

Katarina: I'm of a mixed mind for group activities. Like sometimes I think they're helpful but sometimes it's like...solo we do a lot of translating and just like writing stuff just to practice, here's a quick little prompt, like write a quick response to it...'cause I feel like especially at this level, it's more of just like...use what you know to just get it done.

Language is by nature communicative, and language competence is developed through interactive negotiation. However, these students often isolated themselves within the language classroom. Individual expression using "what you know" and "get[ting] it done" were short-term goals for at least some Spanish for Business students and a valuable means of learning 
Spanish for instrumental purposes. The centrality of the individual was encouraged by the university, as well. Their imposed job preparation practices included crafting a version of the individual online through LinkedIn and on paper through their cover letters and resumes, which students would present in seeking employment. Katarina described this process as necessary. Students were also expected to obtain an internship, with the university's assistance, which would further build the "marketable" version of the individual. These efforts to promote competitive individualism were in service of the university's reputation of producing such successful individuals who are essentially guaranteed to graduate with a job.

An emphasis on the self and on one's own linguistic skills parallels the neoliberal aim Olssen and Peters (2005) described to construct self-interested and self-sufficient individuals. Though many students took up these individualistic discourses, others resisted them through their collaborative practices in the Spanish for Business classroom. Two pairs of students consistently communicated while working on translation activities and helped each other on group work in both Spanish and English. While most students in the class positioned themselves as isolated learners concerned with their own accrual of capital, these few compared answers and exchanged ideas about which lexical items were most appropriate in a business memo, for example, and conferred with one another during whole-class games. These practices illustrated the potential and means to misinterpellate university-sanctioned individualism in the Spanish for Business classroom. By engaging in linguistic negotiation and co-construction of meaning despite the prevalence of messages not only within the classroom but also throughout the campus community and society at-large promoting a self-contained, self-reliant, entrepreneurial, and competitive individual, these few students took up discourses of mutuality and community. Though these seemingly small moments of resistance did not broadly upend the neoliberal practices of the classroom or university, they represent acts wherein "the possibility of genuine structural change presents itself” (Gray, O’Regan \& Wallace, 2018, p. 476).

\section{Discussion}

Neoliberalism and the relations of power it reproduces are prevalent in education and influence how students approach learning and knowledge (Chun, 2015; Holborow, 2007). Students in the Spanish for Business classroom examined in this study took up three discourses crucial to the maintenance of neoliberal structures-competition, compliance with authority, and individualism. Competition in the language classroom reflected the needs of 
the university and the corporate structure. Students sought opportunities to compete with one another, which often also evoked individualistic tendencies to prioritize self-interests at the expense of their classmates. This was especially evident in the game in which students competed for bonus points on an exam. The university, whose primary recruitment strategies involve competitive rankings, has financial interests in their students' competitiveness (Piller $\&$ Cho, 2013). This private institution specializes in business education and profits from producing graduates who will have success in the neoliberal marketplace since the success of graduates attracts new students. Additionally, student advisement discourses at the university essentially assure employment in a company immediately following graduation due to the pressure placed on students throughout their coursework to obtain internships, receive training to prepare for corporate interviews, and refine their job application materials. To increase their competitiveness in the marketplace, some students in the Spanish for Business classroom were invested in language learning in part due to the capital that competence in Spanish would provide (Darvin \& Norton, 2015; Kramsch, 2009). Moreover, competition in neoliberalism is linked to individualism (Giroux, 2011; Gray, O'Regan \& Wallace, 2018; Holborow, 2007). The students' and university's competitive practices overlapped with the valuation of individual success and self-reliance, which are also important in corporate life. In their language learning experiences, the Spanish for Business students maintained an individualistic approach to Spanish learning and use, emphasizing the skills and knowledge they each possessed as individuals rather than engaging in collaborative meaning-making and negotiation that is essential for learning language (Norton \& Toohey, 2011).

Compliance with authority was another neoliberal discourse that Spanish for Business students embodied. In reflection of the hegemonic obedience encouraged in secondary schools (Apple, 2004), the dynamics of power in the university classroom demonstrated a clear division of power between the instructor and students and among more and less powerful students, as well. Students were also expected to comply with the university's systems of job preparation. Again, these systems and compliance therein hindered critical inquiry in the classroom (Martin-Sanchez \& Flores-Rodriguez, 2018) and served the competitive neoliberal goals of the university within the broader societal domain of the free market (Piller \& Cho, 2013).

Overall, the neoliberal practices of the university and of its students represent the "conversion of education into a service, learning into a product and a degree into a cash transaction" (Holborow, 2007, p. 61). In the context 
of the Spanish for Business classroom, such practices at times led to alienation and elicited self-serving discourses. However, while language learning may serve capitalist ends, which value hegemonic control and perpetuate inequities, it may challenge them, as well. Neoliberalism, after all, does not operate in a deterministic manner (Rowe et al., 2019), and potential for the interpellation of contradictory discourses and resistance exists in the language classroom through the development of criticality and student agency. Language instructors may play a role in disrupting neoliberal structures through their pedagogical practices. Critical pedagogies, which approach education as a means of "creating the formative culture of beliefs, practices, and social relations that enable individuals to wield power, learn how to govern, and nurture a democratic society that takes equality, justice, shared values, and freedom seriously" (Giroux, 2011, p. 4), may approach language for business courses as opportunities to question existing structures. When sharing my findings with the instructor of the Spanish for Business course throughout the iterative data analysis process, for example, we discussed the patterns that were emerging in the classroom discourses and how the content and structure of the lessons enabled and reinforced those meanings. We collaborated on planning future Spanish for Business lessons focused on critical material selection, such as the use of a news article addressing the impact of business on the environment in South America, and development of student discussion topics with the goals of questioning neoliberal business practices, in part through philosophical inquiry (see, e.g., Echeverria \& Hannam, 2013), and supporting students' agency to resist them as businesspeople. Through such critical dialogue among stakeholders in education, the language for business classroom may be a site for interrupting neoliberal discourses.

\section{Conclusion}

The discourses taken up by university students within the multidimensional contexts invoked in the classroom, including those of the educational institution and of the neoliberal marketplace that awaits them post-graduation, impact how they are positioned and how they position themselves. In the context of language for business classes, the discourses of neoliberalism are especially prevalent. The instructors of these courses and the students who choose to participate may consent to the seemingly naturalized ideologies that view language as a commodity and encourage competition among peers, compliance with more powerful entities, and individualistic positionalities. This approach to language can serve the capitalist needs of future businesspeople. It is not, however, inevitable. 
Though neoliberal ideology is hegemonic and increasingly global, students, instructors, and researchers may jointly resist capitalist discourses and initiate change through critical pedagogical practices in language classrooms. Within the scope of a given course, the instructor plays a central role in constructing critical pedagogies (e.g., Chun, 2009; Giroux, 2011). By committing both to curricula and materials that expose the issues of neoliberal practices throughout society and to developing language-focused activities that also engage students in critical analyses of hegemonic assumptions, instructors may promote resistance of capitalist discourses. Such activities may involve questioning why specific meanings are constructed in particular ways, how language enables those meanings, and whose voices are valued. Course instructors must also consider the ways participation in language learning and use is structured in the classroom and work toward agentive student engagement ( $\mathrm{Au}, 2018$; Echeverria \& Hannam, 2013). At the institutional level, department and college administrators may also shift the discourses of language education by promoting the humanistic and affective functions of language (MLA, 2007). Rather than learning language to gain an individual competitive edge, resistance involves "learning for...life" (Piller \& Cho, 2013, p. 29). It also requires a commitment to approaching learning and knowledge with a critical lens and to engaging in linguistic and cultural practices that actively deconstruct neoliberal ideologies. This venture, while complex and challenging, may eventually lead to liberation and equity.

\section{References}

Agar, M. H. (1996). The professional stranger. San Diego: Academic Press.

Apple, M. (2004). Ideology and curriculum. New York: Routledge.

Aronowitz, S. (2008). Against schooling: For an education that matters. New York: Paradigm Publishers.

Au, W. (2018). A Marxist education. Chicago: Haymarket Books.

Bergman, M. E., Watrous-Rodriguez, K.M., \& Chalkley, K. M. (2008). Identity and language: Contributions to and consequences of speaking Spanish in the workplace. Hispanic Journal of Behavioral Sciences, 30(1), 40-68.

Block, D. (2007). The rise of identity in SLA research, post Firth and Wagner (1997). The Modern Language Journal, 91, 863-876.

Bourdieu, P. (1991). Language and symbolic power. Cambridge, UK: Polity Press.

Cameron, D., Frazer, E., Harvey, P., Rampton, M, \& Richardson, K. (1992). Researching language: Issues of power and method. London: Routledge.

Canagarajah, S. (2006). Ethnographic methods in language policy. In T. Ricento (Ed.), An introduction to language policy: Theory and method (pp. 153-169). London: Blackwell.

Chun, C. W. (2009). Contesting neoliberal discourses in EAP: Critical praxis in an IEP classroom. Journal of English for Academic Purposes, 8, 111-120. 
Chun, C. W. (2015). Power and meaning making in an EAP classroom: Engaging with the everyday. Tonawanda, NY: Multilingual Matters.

Chun, C. W. (2016). The dominant and everyday discourses of neoliberalism and globalization. In J. Flowerdew, \& J. E. Richardson, (Eds.), The Routledge Handbook of Critical Discourse Studies. London: Routledge.

Cicourel, A. V. (1992). Examples from medical encounters. In A. Duranti, \& C. Goodwin (Eds.), Rethinking context (pp. 293-310). New York: Cambridge University Press.

Cummins, J., Hu, S., Markus, P., \& Kristiina Montero, M. (2015). Identity texts and academic achievement: Connecting the dots in multilingual school contexts. TESOL Quarterly, 49(3), 555-581.

Curran, V. (1993). Developing and teaching a foreign-language course for law students. Journal of Legal Education, 43(4), 598-605.

Darvin, R., \& Norton, B. (2015) Identity and a model of investment in applied linguistics. Annual Review of Applied Linguistics, 35, 36-56.

DeCosta, P., Park, J., \& Wee, L. (2016). Language learning as linguistic entrepreneurship: Implications for language education. The Asia-Pacific Education Researcher, 25(5), 695-702.

Echeverria, E., \& Hannam, P. (2013). Philosophical inquiry and the advancement of democratic praxis. Journal of Pedagogy, 4(1), 111-125.

Eckert, P. (1989). Jocks and burnouts: Social categories and identity in the high school. New York: Teachers College Press, Columbia University.

Faircloth, B. S. (2012). "Wearing a mask" vs. connecting identity with learning. Contemporary Educational Psychology, 37(3), 186-194.

Foucault, M. (1981). The order of discourse. In R. Young (Ed.), Untying the text: A post-structuralist reader (pp. 48-78). Boston: Routledge.

Fryer, T. B. (2012). Languages for specific purposes businesses curriculum creation and implementation in the United States. Modern Language Journal, 96, 122-139

Giroux, H. A. (2011). Critical pedagogy in dark times. In H. A. Giroux (Ed.), On critical pedagogy (pp. 3-15). London: Bloomsbury Academic.

Goffman, E. (1964). The neglected situation. American Anthropologist, 66(6), 133136.

González, J. M. (Ed.) (2008). Encyclopedia of bilingual education (Vols. 1-2). Thousand Oaks, CA: SAGE Publications, Inc.

Goodwin, C., \& Duranti, A. (1992). Rethinking context: An introduction. In A. Duranti, \& C. Goodwin (Eds.), Rethinking context (pp. 1-42). New York: Cambridge University Press.

Gray, J., O'Regan, J. P., \& Wallace, C. (2018). Education and the discourse of global neoliberalism. Language and Intercultural Communication, 18(5), 471-477.

Grosse, C. (1982). A survey of Spanish for business at AACSB colleges and universities in the United States. Modern Language Journal, 66(4), 383-390.

Gumperz, J. J. (1992). Contextualization and understanding. In A. Duranti, \& C. Goodwin (Eds.), Rethinking context (pp. 230-252). New York: Cambridge University Press.

Hadley, G. (2015). English for academic purposes in Neoliberal Universities: A critical grounded theory. London: Springer. 
Hall, S. (1996). Introduction: Who needs 'identity'?. In S. Hall, \& P. du Gay (Eds.), Questions of cultural identity (pp. 1-17). London: SAGE Publications.

Harland, T., Tidswell, T., Everett, D., Hale, L., \& Pickering, N. (2010). Neoliberalism and the Academic as Critic and Conscience of Society. Teaching in Higher Education, 15(1), 85-96.

Harvey, D. (2005). A brief history of neoliberalism. Oxford University Press.

Hymes, D. (1996). What is ethnography? In D. Hymes (Ed.), Ethnography, linguistics, narrative inequality: Toward an understanding of voice (pp. 3-16). Bristol, PA: Taylor $\&$ Francis.

Heath, S. B., \& Street, B. V. (with Mills, M.) (2008). On ethnography: Approaches to language and literacy research. New York: Teachers College Press.

Holborow, M. (2007). Language, ideology and neoliberalism. Journal of Language and Politics, 6(1), 51-73.

Kramsch, C. (2009). The multilingual subject. New York: Oxford University Press.

Lindholm-Leary, K. (2000). Biliteracy for a global society: An idea book on dual language education. Washington, DC: George Washington University.

Long, M. K., \& Uscinski, I. (2012). Evolution of languages for specific purposes programs in the United States: 1990-2011. Modern Language Journal, 96(Supplement 1), 173-189.

Looney, D., \& Lusin, N. (2018). Enrollments in languages other than English in United States institutions of higher education, summer 2016 and fall 2016: Preliminary report. The Modern Language Association of America. Retrieved from https://www. mla.org/content/download/83540/2197676/2016-Enrollments-Short-Report.pdf Martel, J. R. (2017). The misinterpellated subject. Durham, NC: Duke University Press. Martin-Sanchez, M., \& Flores-Rodriguez, C. (2018). Freedom and obedience in western education, Journal of Pedagogy, 9(2), 55-78.

Modern Language Association. (2007). Foreign languages and higher education: New structures for a changed world. Retrieved March 4, 2019, from https://www. mla.org/Resources/Research/Surveys-Reports-and-Other-Documents/TeachingEnrollments-and-Programs/Foreign-Languages-and-Higher-Education-New-Structures-for-a-Changed-World

Morgan, B. (2004). Teacher identity as pedagogy: Towards a field-internal conceptualisation in bilingual and second language education. International Journal of Bilingual Education and Bilingualism, 7(2-3), 172-188.

Norton, B. (2000). Identity and language learning: Gender, ethnicity and educational change. Harlow, England: Longman/Pearson Education.

Norton, B. \& Toohey, K. (2004). Critical pedagogies and language learning: An introduction. In B. Norton, \& K. Toohey (Eds.), Critical pedagogies and language learning (pp. 1- 18). New York: Cambridge University Press.

Norton, B., \& Toohey, K. (2011). Identity, language learning, and social change. Language Teaching, 44(4), 412-446.

Norton Peirce, B. (1995). Social identity, investment, and language learning. TESOL Quarterly, 29(1), 9-31.

Olssen, M., \& Peters, M. (2005). Neoliberalism, higher education and the knowledge economy: From the free market to knowledge capitalism. Journal of Education Policy, 20(3), 313-345. 
Piekkari, R., Welch, D. E., \& Welch, L. S. (2014). Language in international business: The multilingual reality of global business expansion. Northampton, MA: Edward E1gar Publishing.

Piller, I., \& Cho, J. (2013). Neoliberalism as language policy. Language in Society 42(1), p. 23-44.

Plastina, A. F. (2016). Putting the plain into pain language in English for medical purposes: Learner inquiry into patients' online descriptive accounts. Language Learning in Higher Education, 6(1), 207-228.

Rowe, E., Lubienski, C., Skourdoumbis, A., Gerrard, J., \& Hursh, D. (2019). Exploring alternatives to the 'neoliberalism' critique: New language for contemporary global reform. Discourse: Studies in the Cultural Politics of Education, 4O(2), 147-149

Schegloff, E. A. (1992). In another context. In A. Duranti, \& C. Goodwin (Eds.), Rethinking context (pp. 191-227). New York: Cambridge University Press.

Serafini, E. J., \& Torres, J. (2015). The utility of needs analysis for nondomain expert instructors in designing task-based Spanish for the professions curricula. Foreign Language Annals, 48(3), 447-472.

Swales, J. (1988). Episodes in ESP. A source and reference book on the development of English for Science and Technology. New York: Prentice Hall International Ltd.

Talmy, S. (2010). Becoming "local" in ESL: Racism as resource in a Hawai'i public high school. Journal of Language, Identity, and Education, 9(1), 36-57.

U.S. Department of Education. (2018). Title VI centers for international business education list of FY 2018-2021 grantee institutions and award amounts. Retrieved March 4, 2019, from https://www2.ed.gov/programs/iegpscibe/index.html

Urciuoli, B. (2016). The compromised pragmatics of diversity. Language \& Communication, 51, 30-39.

van Leeuwen, T. (2008). Discourse and practice: New tools for critical discourse analysis. New York: Oxford University Press.

Willis, P. (1977). Learning to labor: How working class kids get working class jobs. New York: Columbia University Press.

\section{Author}

Jesse W. Rubio, Ph.D. Candidate

University of Massachusetts Boston

William T, Morrissey Blvd, 100

02125 Boston

USA

Email: Jesse.Rubio001@umb.edu 